\title{
Periodic flooding restrains local succession of microphytobenthos in floodplain lakes
}

\author{
E. Van der Grinten ${ }^{1,2}$, W. Admiraal ${ }^{2}$ and M. H. S. Kraak ${ }^{2, *}$
}

With 5 figures and 3 tables

\begin{abstract}
Periodic flooding of river floodplains and connectivity of floodplain lakes and rivers is suggested to interfere with the succession of microphytobenthos. To analyse this we: 1 . studied the impact of flooding on the relationship between irradiance level (depth) and microphytobenthic community composition; 2 . sampled three lakes with different connection-disconnection patterns; and 3. studied seasonal variation in community composition in one floodplain lake subjected to several flooding events. Shortly after flooding and subsequent connection of floodplain lakes, microphytobenthic communities showed a uniform species composition. Disconnection of the lakes was followed by a succession of species according to local environmental conditions. However, assemblages were often set back before outgrowth of local species or divergence of community composition became prominent. It is therefore concluded that flooding and the associated connection-disconnection regime of floodplain waters overrule the selective effects of local environmental parameters.
\end{abstract}

Key words: Microphytobenthos, periphyton, sediment, succession, floodplain lakes, flooding, connection, community composition.

\section{Introduction}

In highly dynamic environments, microphytobenthic communities may be frequently disturbed (Biggs 1995) and mixed, potentially masking the relationships between local environmental gradients and microphytobenthic community composition (Soininen 2007). Floodplains of large lowland rivers are such highly dynamic environments: during flooding the floodplain becomes inundated and the floodplain lakes become connected to the main river. At that time the suspension and sedimentation of the sediment top layer is intense, while during low water the floodplain lakes become disconnected from the main stream and develop according to local conditions (Ward \& Stanford 1995, Pithart 1999).
The present study aims to analyze how flooding of a river and the consequent connection of the floodplain lakes and the river interfere with the relationship between microphytobenthic community composition and local environmental conditions. We expect that during flooding the connection of the lakes will result in mixing and redistribution of species, leading to a uniform species composition. In disconnected floodplain lakes microphytobenthic communities may diverge according to local conditions.

To study the effect of these connection-disconnection patterns on microphytobenthic community composition, we sampled three lakes at different distances from the river Waal, the Netherlands, representing different connection-disconnection patterns. Secondly we studied seasonal variation in community composi-

\footnotetext{
${ }^{1}$ Authors' addresses: National Institute for Public Health and the Environment, P. O. Box 1, 3720 BA Bilthoven, The Netherlands.

${ }^{2}$ Department of Aquatic Ecology and Ecotoxicology, IBED, University of Amsterdam, Kruislaan 320, 1098 SM Amsterdam, The Netherlands.

* Author for correspondence; e-mail: m.h.s.kraak@uva.nl
} 
tion in one floodplain lake which was subjected to several flooding events. Finally we studied the relationship between a single environmental factor (irradiance level) and microphytobenthic community composition after flooding by sampling microphytobenthos along a depth gradient in a single floodplain lake. Irradiance level was chosen because of the relationship between microphytobenthic community composition and light quantity (Hill 1996, Dodds et al. 1999, Wellnitz \& Rinne 1999, Tuji 2000, Kralj et al. 2006).

\section{Material and methods}

\section{Study area}

The sampled lakes are situated in floodplains of the river Waal, the main channel of the River Rhine in the Netherlands (Fig. 1). The plains are partly used for pasturing cattle and also serve as a foraging and resting place for birds. Clay deposits were exploited in the past and now a man-made semi-natural landscape dominates. The floodplain and the lakes are embedded between a low summer dike and a high winter dike, leading to seminatural flood dynamics.

Three lakes were selected for the present study. Lake Och5 is a relatively large lake (ca. $800 \mathrm{~m}$ long, estimated average depth $2.5 \mathrm{~m}$ ), which is always connected to the main stream of the river, and consequently, the water level fluctuates with the water level of the river. The sediment is composed of coarse sand. Lake DeO4 is small $(50 \times 50 \mathrm{~m}$, average depth $2 \mathrm{~m})$ and is connected during $50-150$ days a year. It is dominated by macrophytes in summer, but the present study concentrates on unvegetated patches of the lake. The sediment is silty and rich in organic matter and tends to be anoxic. Lake DeO1 is a shallow lake (average depth $2 \mathrm{~m}$ ) with highly fluctuating water levels caused by flooding, precipitation and evaporation, leading to highly variable dimensions of the lake (maximal size $200 \times$ $50 \mathrm{~m}$ ). In dry summers the lake evaporates completely, whereas in wet winters it becomes connected to neighbouring lakes. It is connected during 2-20 days a year. The sediment is composed of fine sand and silt. When the river is flooded and the plains are inundated, all floodplain lakes become connected to the main stream, and after the flood they become disconnected again.

The time course of the sampling campaigns and the flooding regime of the river are illustrated in Fig. 2. The highest bars indicate the dates when the river water level is as high as or higher than the summer dike and the floodplains are inundated. The lower bars indicate after-flood recovery and onset of disconnection, the dates when river water level drops from floodlevel to 1 meter below the level of the summer dike (original water level data were from Rijkswaterstaat, 2003). The moment each lake is connected, and becomes disconnected again, and consequently also the duration of the connection varies with distance to the river, height of the dikes, and other factors. The spatio-temporal characteristics of the impact of different flooding regimes are reflected in the dynamics of nutrients and conductivity (Fig. 3). The two southern lakes (DeO1 and DeO4) become $\mathrm{NO}_{3}$ and $\mathrm{SiO}_{2}$ depleted when they are isolated and are replenished when the plains are flooded. The parameters for the connected lake (Och5) follow those for the river.

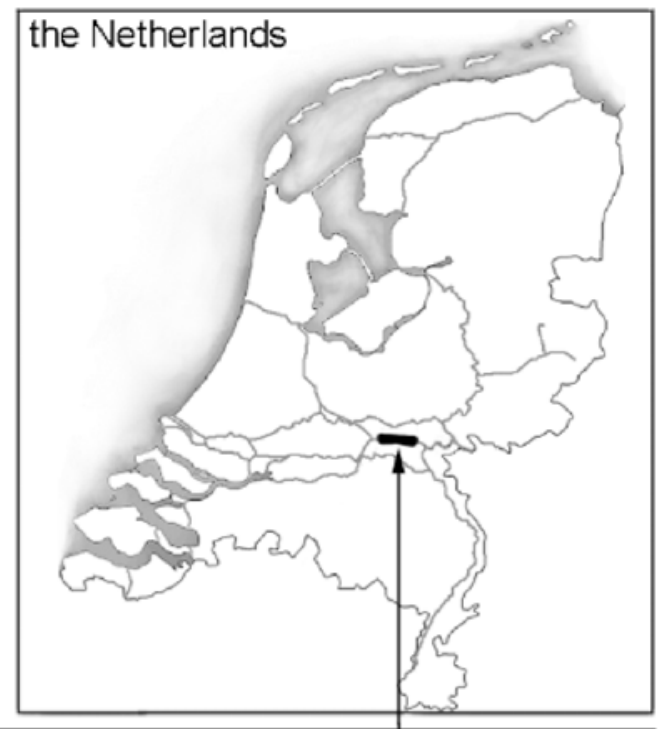

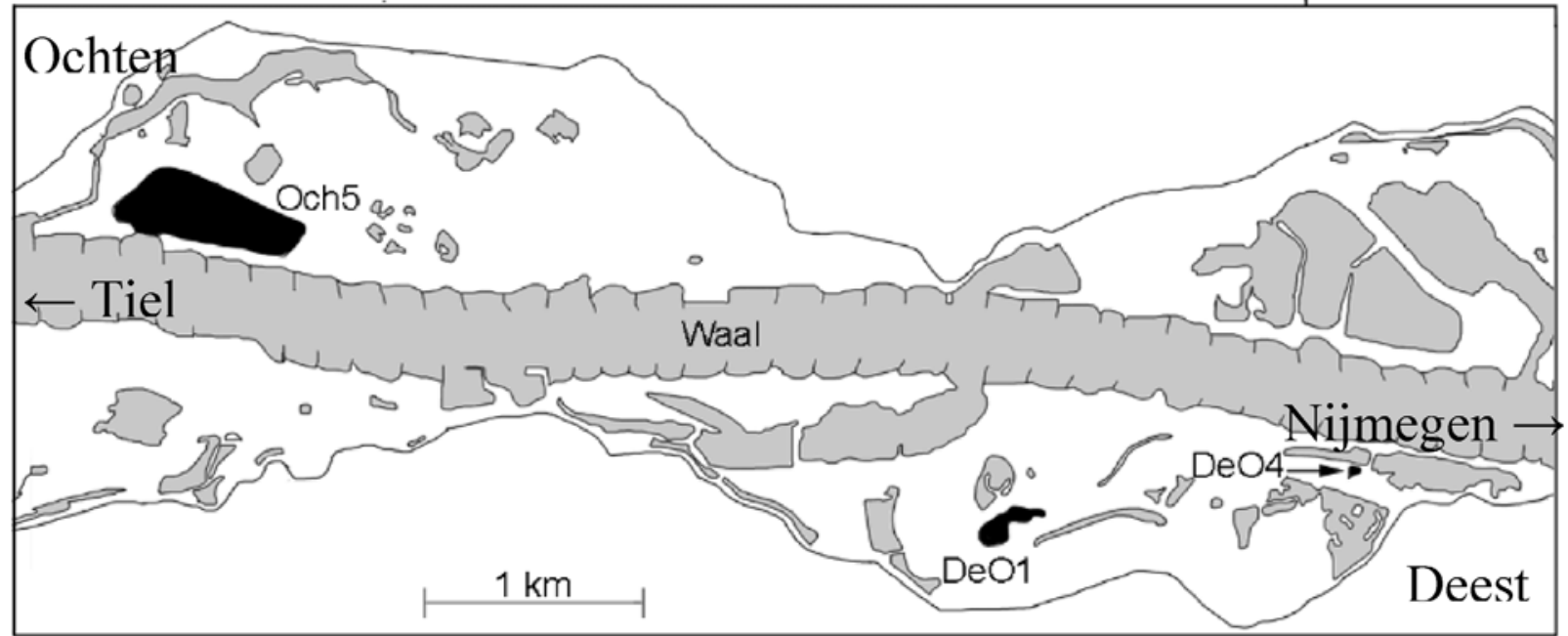

Fig. 1. Locations of the sampled floodplains lakes (black) of the River Waal (The Netherlands, $51^{\circ} \mathrm{N} 5^{\circ} \mathrm{E}$ ). 


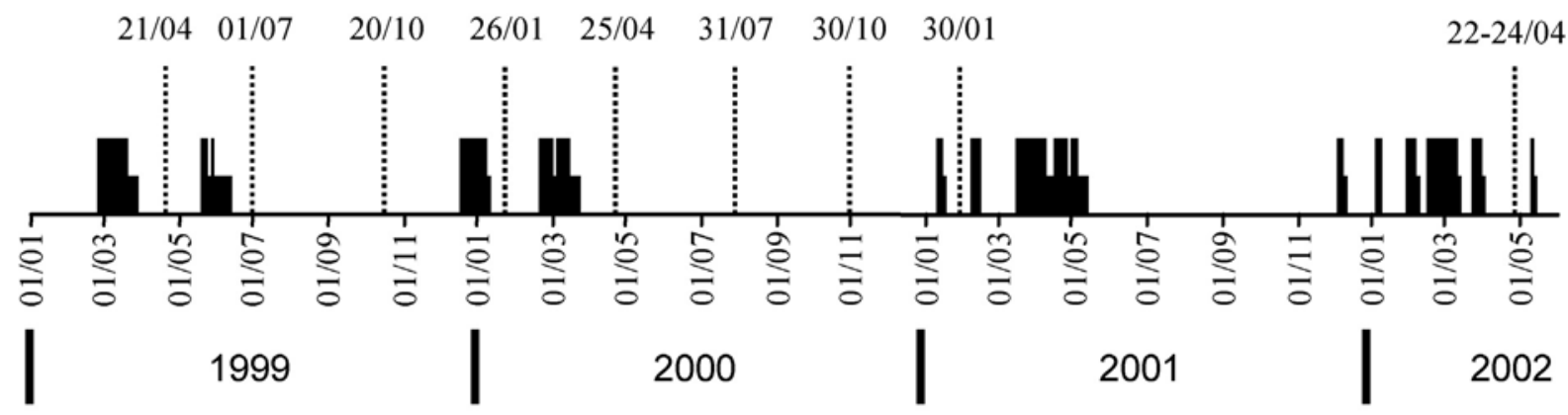

Fig. 2. Time course of the samplings and flooding history of the river. The vertical dotted lines indicate the sampling dates. The highest bars indicate the dates when the river water level was as high as or higher than the summer dike and the floodplains were inundated. The lower bars indicate after-flood recovery and onset of isolation, the dates when river water level dropped to 1 meter below the height of the summer dike (original water level data were from Rijkswaterstaat 2003).
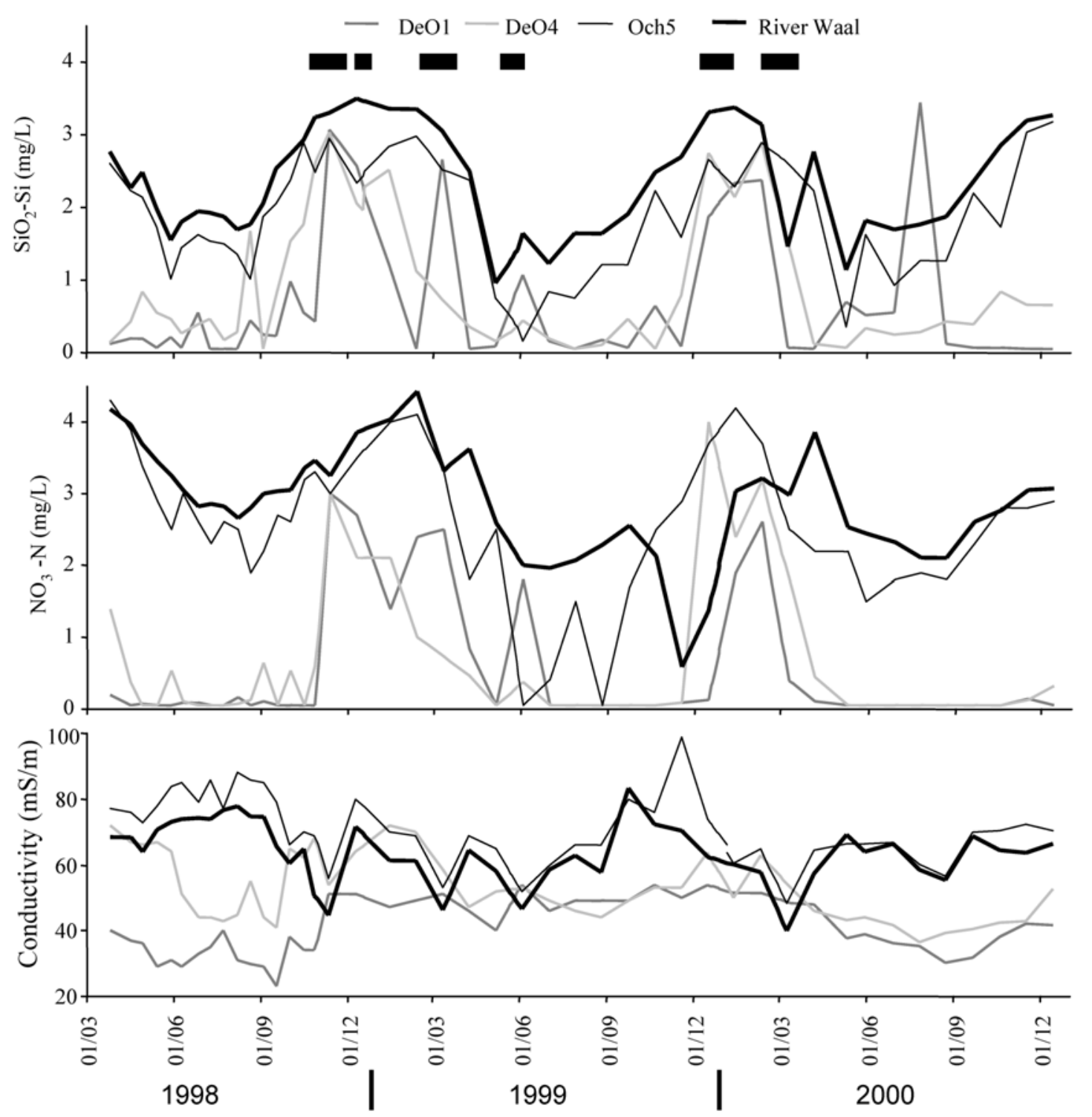

Fig. 3. Concentrations of $\mathrm{SiO}_{2}$ and $\mathrm{NO}_{3}$ and conductivity in the three floodplain lakes DeO1, DeO4 and Och 5 (connected) from 1998 to 2000 (data from RIZA) and for the main stream river of the river Waal (bold black line, data from Rijkswaterstaat 2003). The black bars at the top of the figure indicate the periods of time that the river inundated all of the floodplains. 


\section{Sampling}

To study if a relationship between irradiance level and microphytobenthic community composition was established 22-24 days after flooding a depth gradient (of 10,75 and $200 \mathrm{~cm}$ ) in a single lake (DeO1) was sampled twice with a two days interval in spring 2002 (Table 1a). Secondly, to study the effect of differences in the frequency and duration of connection all three lakes were sampled twice, in spring 1999 and in spring 2000, at a depth of $10 \mathrm{~cm}$ (Table $1 \mathrm{~b}, \mathrm{c})$. Finally, temporal variation within one lake (DeO1) was studied. This lake was sampled in all seasons for two subsequent years (1999 and 2000) at a depth of $10 \mathrm{~cm}$, creating large differences in the time between sampling and the latest flooding, varying from 19 days in January 2001 to 232 days in November 2000 (Table 1b,c).

At each sampling date conductivity, $\mathrm{pH}$, temperature and light attenuation was measured (Table 1). Replicate cores were taken from the sediment using cut-off polypropylene syringes with a sharpened edge $\left(\right.$ Terumo ${ }^{\circledR}$, diameter $1.5 \mathrm{~cm}$, volume $50 \mathrm{ml}$ ), at a distance of $10-30 \mathrm{~cm}$ parallel from each other. The cores were completely filled with sediment and water and closed with a stopper and transported to the laboratory in cooled containers. In the laboratory, slices of the top $3 \mathrm{~mm}$ of the cores were cut after pushing the sediment upwards with the syringe stopper. Slices of 3 to 6 replicate cores were pooled and composite samples diluted ( $200 \mathrm{ml}$ filtered lake water per slice).
This slurry was stirred with a magnetic stirrer and an aliquot of homogenized slurry was fixed with Lugol's iodine.

In the depth gradient 6 additional cores per depth were taken to measure chlorophyll $a$ in the top $3 \mathrm{~mm}$ slices of each individual core according to Lorenzen (1967). The chlorophyll- $a$ data were tested for significant differences by One-Way ANOVA followed by a Post Hoc test (SNK).

\section{Identification and counting}

The fixed samples were first examined at a magnification of $1000 \times$ with a light microscope (Olympus $\mathrm{BH} 2$ ) and species were identified as intact cells, according to Bourrelly (19661970), Krammer \& Lange-Bertalot (1986-1991), Anagnostidis $\&$ Komarek (1988) and Cox (1996). Some species were grouped into a single taxon because Cox's key does not allow determination to the species level, e.g. for Nitzschia we distinguished several size groups rather than individual species.

Chlorophyll-containing algal cells that were alive when sampled were counted on temporary slides at $400 \times$ magnification. Single-celled taxa were enumerated and for filamentous cyanobacteria and chlorophytes a $50 \mu \mathrm{m}$ length of filament was counted as one individual. Algal cells were identified to the lowest taxonomic level possible. Per sample 4-8 sub-samples were counted, adding up to a total of 500-600 single cells or filaments.

Table 1. Dates of the sampling campaigns and physico-chemical characteristics of the sampling sites. a) depth gradient in lake DeO1. b) \& c) three lakes representing differences in inundation-isolation pattern and seasonal variation in lake DeO1.

\begin{tabular}{|c|c|c|c|c|c|c|}
\hline $\mathbf{a}$ & $\begin{array}{l}10 \mathrm{~cm} \\
\mathrm{DeO} 1 \\
\text { spring } \\
2002\end{array}$ & $\begin{array}{l}75 \mathrm{~cm} \\
\mathrm{DeO} 1 \\
\text { spring } \\
2002\end{array}$ & $\begin{array}{l}200 \mathrm{~cm} \\
\mathrm{DeO} 1 \\
\text { spring } \\
2002\end{array}$ & $\begin{array}{l}10 \mathrm{~cm} \\
\mathrm{DeO} 1 \\
\text { spring } \\
2002\end{array}$ & $\begin{array}{l}75 \mathrm{~cm} \\
\mathrm{DeO} 1 \\
\text { spring } \\
2002\end{array}$ & $\begin{array}{l}200 \mathrm{~cm} \\
\mathrm{DeO} 1 \\
\text { spring } \\
2002\end{array}$ \\
\hline Date $(\mathrm{m} / \mathrm{d} / \mathrm{y})$ & $22 / 04 / 02$ & $22 / 04 / 02$ & $22 / 04 / 02$ & $24 / 04 / 02$ & $24 / 04 / 02$ & $24 / 04 / 02$ \\
\hline time after last flooding (days) & 24 & 24 & 24 & 26 & 26 & 26 \\
\hline $\begin{array}{l}\text { temperature at sed. surf. }\left({ }^{\circ} \mathrm{C}\right) \\
\mathrm{pH} \text { at sed surf. } \\
\mathrm{O}_{2}(\mathrm{mg} / \mathrm{L}) \\
\mathrm{O}_{2}(\%) \\
\text { Conductivity }(\mathrm{mS} / \mathrm{m}) \\
\% \text { of incidence irradiance } \\
\text { mg chl } a / \mathrm{m}^{2}( \pm 1 \mathrm{SD})\end{array}$ & $\begin{array}{l}17 \\
9.3 \\
14 \\
135 \\
36.8 \\
76.5 \\
177 \pm 39\end{array}$ & $\begin{array}{l}14.9 \\
9.3 \\
15.3 \\
151 \\
36.8 \\
13.4 \\
115 \pm 23\end{array}$ & $\begin{array}{l}11.7 \\
9.12 \\
12.45 \\
118 \\
37.7 \\
0.47 \\
45 \pm 12\end{array}$ & $\begin{array}{l}20.2 \\
9.25 \\
14.9 \\
160 \\
36.8 \\
67.7 \\
143 \pm 31\end{array}$ & $\begin{array}{l}17.2 \\
9.36 \\
13.8 \\
145 \\
36.9 \\
5.4 \\
69 \pm 15\end{array}$ & $\begin{array}{l}15.2 \\
9.03 \\
11.25 \\
112 \\
38.1 \\
0.04 \\
43 \pm 16\end{array}$ \\
\hline b & $\begin{array}{l}\text { Och5 } \\
\text { spring } \\
1999 \\
\end{array}$ & $\begin{array}{l}\mathrm{DeO} 4 \\
\text { spring } \\
1999 \\
\end{array}$ & $\begin{array}{l}\mathrm{DeO} 1 \\
\text { spring } \\
1999 \\
\end{array}$ & $\begin{array}{l}\text { DeO1 } \\
\text { summer } \\
1999\end{array}$ & $\begin{array}{l}\text { DeO1 } \\
\text { autumn } \\
1999\end{array}$ & $\begin{array}{l}\mathrm{DeO} 1 \\
\text { winter } \\
2000 \\
\end{array}$ \\
\hline Date $(\mathrm{m} / \mathrm{d} / \mathrm{y})$ & 21/04/99 & 21/04/99 & $21 / 04 / 99$ & 01/07/99 & 20/10/99 & $26 / 01 / 00$ \\
\hline $\begin{array}{l}\text { time after last flooding (days) } \\
\text { temperature at sed. surf. }\left({ }^{\circ} \mathrm{C}\right) \\
\mathrm{pH} \text { at sed. surf. } \\
\text { Conductivity }(\mathrm{mS} / \mathrm{m}) \\
\% \text { of incidence irradiance }\end{array}$ & $\begin{array}{l}0 \\
11.3 \\
8.02 \\
69.0\end{array}$ & $\begin{array}{l}34 \\
13.6 \\
8.37 \\
56.1 \\
78.8\end{array}$ & $\begin{array}{l}34 \\
12.8 \\
8.38 \\
43.2 \\
76.7\end{array}$ & $\begin{array}{l}34 \\
18.9 \\
8.15 \\
46.0 \\
77.0 \\
\end{array}$ & $\begin{array}{l}145 \\
5.9 \\
8.75 \\
50.8 \\
65.3 \\
\end{array}$ & $\begin{array}{l}22 \\
1.9 \\
7.94 \\
51.1 \\
73.6 \\
\end{array}$ \\
\hline c & $\begin{array}{l}\text { Och5 } \\
\text { spring } \\
2000 \\
\end{array}$ & $\begin{array}{l}\mathrm{DeO} 4 \\
\text { spring } \\
2000 \\
\end{array}$ & $\begin{array}{l}\mathrm{DeO} 1 \\
\text { spring } \\
2000\end{array}$ & $\begin{array}{l}\text { DeO1 } \\
\text { summer } \\
2000\end{array}$ & $\begin{array}{l}\text { DeO1 } \\
\text { autumn } \\
2000\end{array}$ & $\begin{array}{l}\mathrm{DeO} 1 \\
\text { winter } \\
2001 \\
\end{array}$ \\
\hline Date $(\mathrm{m} / \mathrm{d} / \mathrm{y})$ & $25 / 04 / 00$ & $25 / 04 / 00$ & $25 / 04 / 00$ & $31 / 07 / 00$ & $06 / 11 / 00$ & $30 / 01 / 01$ \\
\hline time after last flooding (days) & 0 & 44 & 44 & 141 & 232 & 19 \\
\hline $\begin{array}{l}\text { temperature at sed. surf. }\left({ }^{\circ} \mathrm{C}\right) \\
\text { pH at sed. surf. }\end{array}$ & $\begin{array}{l}12.8 \\
8.20\end{array}$ & $\begin{array}{l}14.8 \\
9.2\end{array}$ & $\begin{array}{l}14.7 \\
8.51\end{array}$ & $\begin{array}{l}25.6 \\
9.4\end{array}$ & $\begin{array}{l}7.3 \\
8.55\end{array}$ & $\begin{array}{l}1.6 \\
8.04\end{array}$ \\
\hline $\begin{array}{l}\text { Conductivity }(\mathrm{mS} / \mathrm{m}) \\
\% \text { of incidence irradiance }\end{array}$ & 76.2 & 42.5 & 42.6 & 32.3 & 40.7 & 43.0 \\
\hline$\%$ of incidence irradiance & 78.2 & 72.0 & 81.8 & 80.2 & 72.2 & 80.6 \\
\hline
\end{tabular}




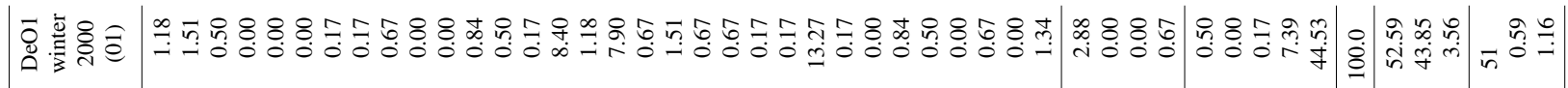

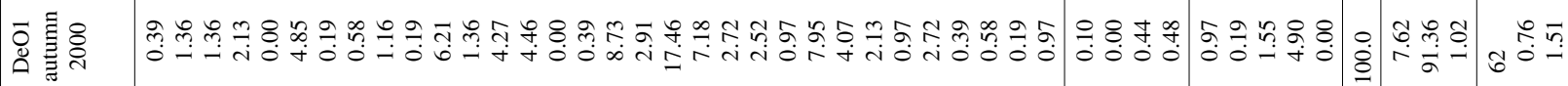

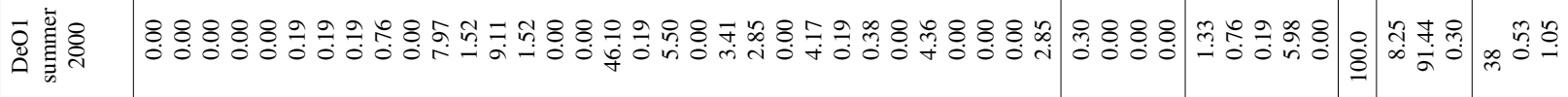

б.

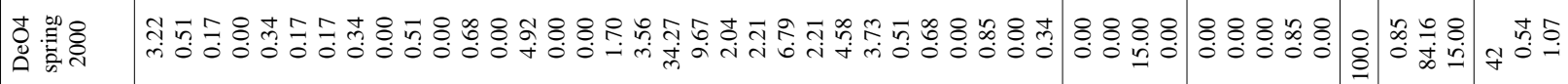

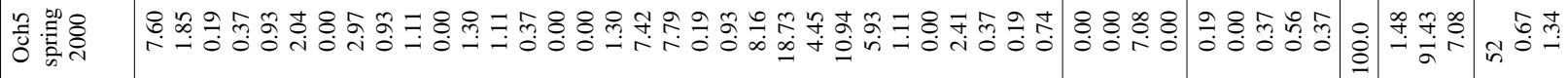

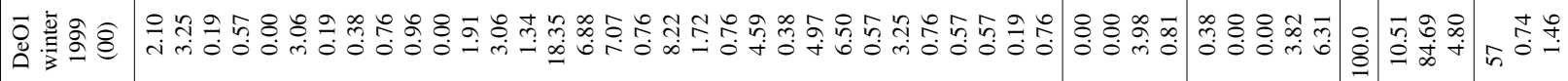

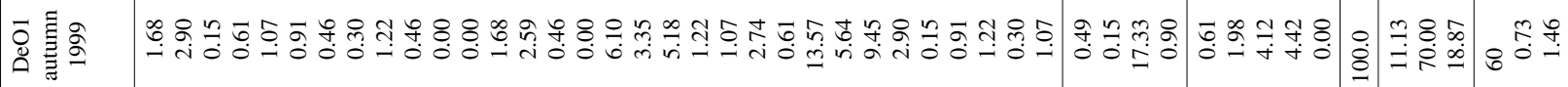

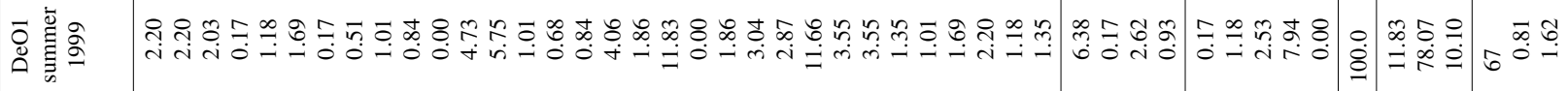

○. :

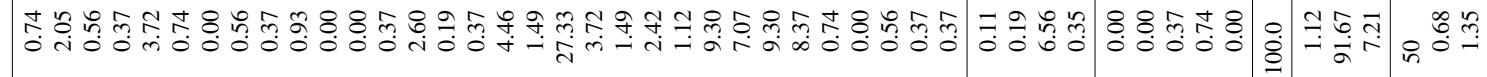

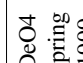

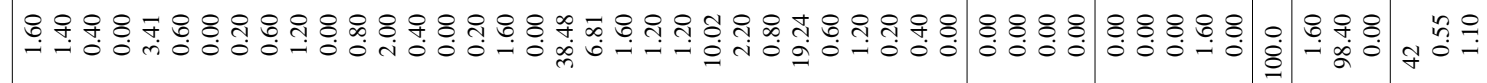

능

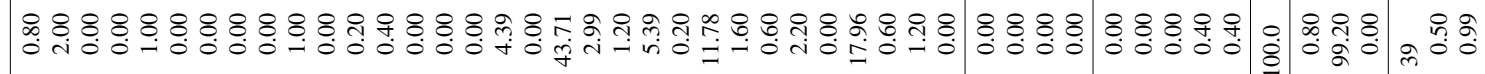

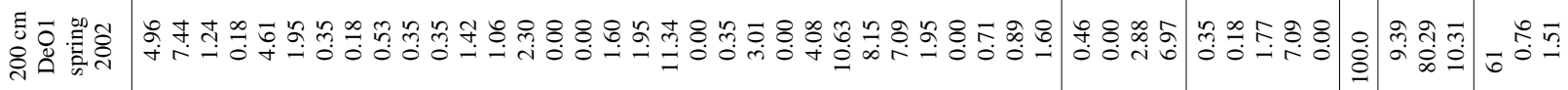

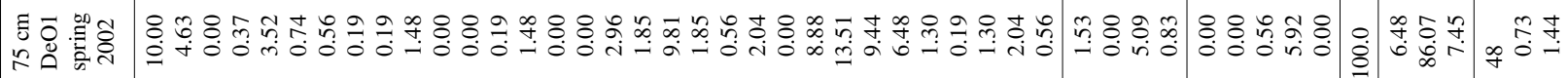

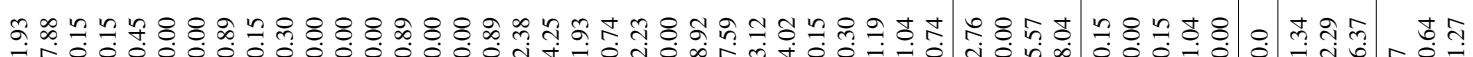

हี

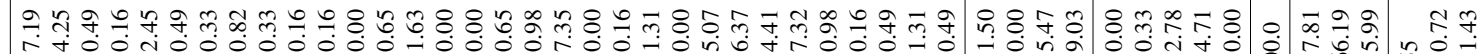

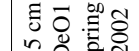

हี

졍 8 m

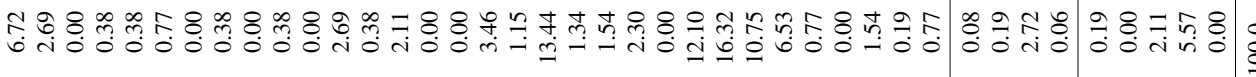

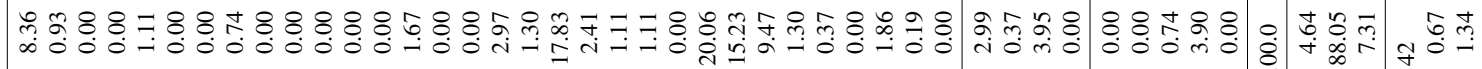

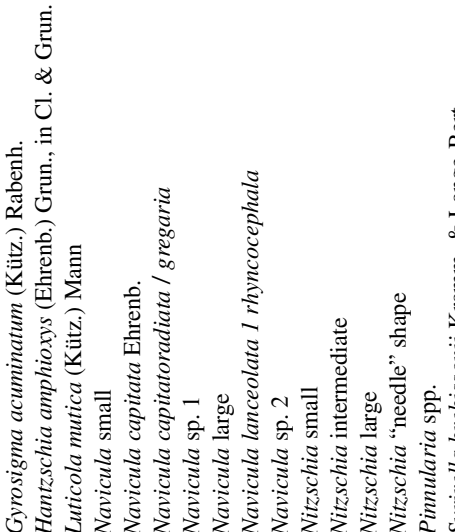

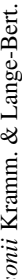

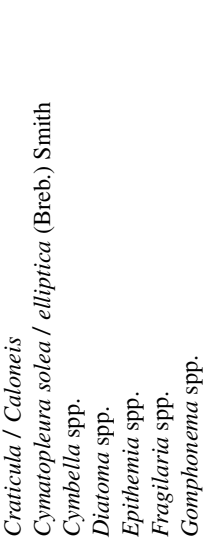


The following community characteristics were calculated: Number of taxa, Shannon-Wiener diversity index $H^{\prime}$ (Shannon \& Weaver 1963), evenness $J^{\prime}$ (Pielou 1966) and Bray-Curtis similarity index $S$ ' (Bray \& Curtis 1957, according to Clarke \& Warwick 1994). The Bray-Curtis similarity index $S$ ' was calculated for all pairs of samples using the expression

$$
S_{j k}^{\prime}=100 *\left(1-\frac{\sum_{i=1}^{n}\left|y_{i j}-y_{i k}\right|}{\sum_{i=1}^{n}\left(y_{i j}+y_{i k}\right)}\right)
$$

With $\mathrm{i}(\mathrm{n})=$ number of taxa, $\mathrm{j}=$ community $\mathrm{j}, \mathrm{k}=$ community $\mathrm{k}$, $y_{i j}=$ fraction of taxon $i$ in community $j, y_{i k}=$ fraction of taxon $i$ in community $\mathrm{k}, S_{\mathrm{jk}}=$ similarity value between communities $\mathrm{j}$ and k. $S$ ' can range from $0 \%$ to $100 \%$ for communities with respectively none and all taxa in common. Values of $>60 \%$ generally are regarded as indicating replicate samples (Engelberg 1987, Gauch 1982).

\section{Results}

\section{Characterization of microphytobenthic communities on floodplain lake sediments}

Diatoms always dominated the communities (64-99\%), except for the winter sample of 2001 (44\%), which was dominated by chlorophytes (53\%) (Table 2). At the other sampling dates relative abundance of chlorophytes ranged from 1-18\%, while cyanobacterial abundance ranged $0-26 \%$ (Table 2). Hardly any community was clearly dominated by one or a few taxa: the highest relative abundance of a single taxon was $43.7 \%$, while the mean of highest relative abundances in all samples was $22.1 \pm 10.7 \%$. (Table 2). Diatoms were mainly represented by members of the motile Nitzschia and Navicula genera. In all except one sample the taxon Navicula capitatoradiata / gregaria was present at more than $5 \%$ abundance, and was the most abundant taxon in 11 of 18 samples. Genera like Achnanthes and Gomphonema that grow attached to solid substrates were scarcely represented, except in sites that were isolated for longer periods of time (Table 2).

\section{Relationship between irradiance level and microphytobenthos}

The percentage of solar irradiance at the water surface reaching the sediment surface ranged from $77 \%$ at $10 \mathrm{~cm}$ water depth to $<0.5 \%$ at a depth of $200 \mathrm{~cm}$ (Table 1a). Accordingly, chlorophyll- $a$ concentrations decreased significantly $(\mathrm{p}<0.05)$ with increasing depth on both sampling dates (Table 1a). Despite the large differences in irradiance and chlorophyll- $a$ between depths, differences in species composition were small (Fig. 4), reflected by similarities of $44-78 \%$ (Table 3a). Yet, the lowest similarities were observed between the shallowest and deepest sites (44-53\%) (Table 3a). Moreover, similarities between the same depth at the two sampling dates were higher than those between different depths at the same sampling day (Table 3a). The number of taxa increased with increasing depth (from $45 \pm 4$ to $58 \pm 4$ taxa) (Table 2), as well as the relative abundance of planktonic diatoms like Asterionella and Fragilaria (from $14.3 \pm 2.2 \%$ to $26.4 \pm$ $0.4 \%$ ) and the relative abundance of chlorophytes (from $3.0 \pm 2.3 \%$ to $13.6 \pm 6.0 \%$ ).

\section{Effect of differences in inundation-isolation pattern}

The location of the three lakes causes differences in frequency and duration of flooding and isolation. Consequently, the time after the last flooding varied from 0-34 days and from 0-44 days in 1999 and 2000, respectively (Table $1 \mathrm{~b}, \mathrm{c}$ ). Yet, communities in the three lakes were very similar in 1999 (53-58\%), and quite similar in 2000 (32-46\%) (Fig. 5, Table 3b). The lower similarities in 2000 coincided with a longer time after the last flooding.

Sampling one lake (DeO1) in all seasons for two subsequent years (1999 and 2000) at a depth of $10 \mathrm{~cm}$, created large time intervals between sampling and the last flooding, varying from 19 days in January 2001 to 232 days in November 2000 (Table 1b,c). Prolonged disconnection coincided with lower similarities: the similarity between spring 2000 (44 days post flooding) and summer 2000 (141 days post flooding) was only $24 \%$ (Table 3c), suggesting that the longer isolation time allowed divergent development of the community. The lowest similarities were observed when reconnection occurred by a new flooding, between winter 2001 (19 days post flooding) and spring, summer and autumn 2000 (44, 141 and 232 days post flooding, respectively) (Table 3c).

In all other cases similarities were higher, but nevertheless, we did find seasonal differences in species composition (Table 2). In winter Hantzschia amphioxys (abundance of 18 and $8 \%$ in 1999 and 2000) and Luticola mutica (abundance 7 and $1.2 \%$ ) were typical, only occurring in very small abundances in the other seasons $(<0.8 \%)$. Amphora libyca had its highest abundance in autumn of both years (0.6 and $2.1 \%)$. Gomphonema spp. had its highest occurrence in both summers (5.7 and 9.1\%). The seasonal variation in species composition was similar for all sampling years, confirmed by the high similarities between the $\mathrm{DeO} 1$ spring samples from 1999, 2000 and 2002 (53-64\%, Table 3c). 
Table 3. Bray-Curtis similarity indices $\left(S^{\prime}\right)$. a) depth gradient in lake DeO. b) \& c) three lakes representing differences in inundation-isolation pattern and seasonal variation in lake DeO1. Values of $>60 \%$ (bold) generally are regarded as indicating replicate samples (Engelberg 1987, Gauch 1982).

\begin{tabular}{|c|c|c|c|c|c|c|c|}
\hline $\mathbf{a}$ & $\begin{array}{l}10 \mathrm{~cm} \\
\mathrm{DeO} 1 \\
22 / 04 / 02\end{array}$ & $\begin{array}{l}75 \mathrm{~cm} \\
\mathrm{DeO} 1 \\
22 / 04 / 02\end{array}$ & $\begin{array}{l}200 \mathrm{~cm} \\
\mathrm{DeO} 1 \\
22 / 04 / 02\end{array}$ & $\begin{array}{l}10 \mathrm{~cm} \\
\mathrm{DeO} 1 \\
24 / 04 / 02\end{array}$ & $\begin{array}{l}75 \mathrm{~cm} \\
\mathrm{DeO} 1 \\
24 / 04 / 02\end{array}$ & & \\
\hline $\begin{array}{r}10 \mathrm{~cm} \mathrm{DeO} 104 / 22 / 02 \\
75 \mathrm{~cm} \mathrm{DeO} 104 / 22 / 02 \\
200 \mathrm{~cm} \mathrm{DeO} 104 / 22 / 02 \\
10 \mathrm{~cm} \mathrm{DeO1} 04 / 24 / 02 \\
75 \mathrm{~cm} \mathrm{DeO} 104 / 24 / 02 \\
200 \mathrm{~cm} \mathrm{DeO1} 04 / 24 / 02\end{array}$ & $\begin{array}{l}\mathrm{x} \\
\mathbf{7 3 . 8} \\
44.1 \\
58.3 \\
\mathbf{7 0 . 9} \\
47.9\end{array}$ & $\begin{array}{l}x \\
54.0 \\
55.0 \\
77.7 \\
\mathbf{6 4 . 6}\end{array}$ & $\begin{array}{l}x \\
52.2 \\
62.5 \\
67.5\end{array}$ & $\begin{array}{l}\mathrm{x} \\
59.0 \\
52.6\end{array}$ & $\begin{array}{l}x \\
66.8\end{array}$ & & \\
\hline b & $\begin{array}{l}\mathrm{DeO} 1 \\
\text { spring } \\
1999\end{array}$ & $\begin{array}{l}\mathrm{DeO} 4 \\
\text { spring } \\
1999\end{array}$ & $\begin{array}{l}\text { Och5 } \\
\text { spring } \\
1999\end{array}$ & $\begin{array}{l}\mathrm{DeO} 1 \\
\text { spring } \\
2000\end{array}$ & $\begin{array}{l}\mathrm{DeO} 4 \\
\text { spring } \\
2000\end{array}$ & & \\
\hline $\begin{array}{l}\text { DeO1 spring } 1999 \\
\text { DeO4 spring } 1999 \\
\text { Och5 spring } 1999 \\
\text { DeO1 spring } 2000 \\
\text { DeO4 spring } 2000 \\
\text { Och5 spring } 2000 \\
\end{array}$ & $\begin{array}{l}\mathrm{x} \\
58.3 \\
52.6 \\
\mathbf{6 0 . 3} \\
58.3 \\
45.2\end{array}$ & $\begin{array}{l}\mathrm{x} \\
58.2 \\
42.7 \\
53.9 \\
26.9 \\
\end{array}$ & $\begin{array}{l}x \\
42.7 \\
48.8 \\
30.5 \\
\end{array}$ & $\begin{array}{l}x \\
45.6 \\
31.6\end{array}$ & $\begin{array}{l}x \\
46.4\end{array}$ & & \\
\hline c & $\begin{array}{l}\mathrm{DeO} 1 \\
\text { spring } \\
1999\end{array}$ & $\begin{array}{l}\text { DeO1 } \\
\text { summer } \\
1999\end{array}$ & $\begin{array}{l}\text { DeO1 } \\
\text { autumn } \\
1999\end{array}$ & $\begin{array}{l}\mathrm{DeO} 1 \\
\text { winter } \\
2000\end{array}$ & $\begin{array}{l}\mathrm{DeO} 1 \\
\text { spring } \\
2000\end{array}$ & $\begin{array}{l}\text { DeO1 } \\
\text { summer } \\
2000\end{array}$ & $\begin{array}{l}\mathrm{DeO} 1 \\
\text { autumn } \\
2000\end{array}$ \\
\hline $\begin{array}{l}\text { DeO1 spring } 1999 \\
\text { DeO1 summer } 1999 \\
\text { DeO1 autumn } 1999 \\
\text { DeO1 winter } 2000 \\
\text { DeO1 spring } 2000 \\
\text { DeO1 summer } 2000 \\
\text { DeO1 autumn } 2000 \\
\text { DeO1 winter } 2001\end{array}$ & \begin{tabular}{l|l}
$x$ \\
50.0 \\
57.1 \\
43.7 \\
$\mathbf{6 0 . 3}$ \\
21.0 \\
52.4 \\
16.8
\end{tabular} & $\begin{array}{l}\mathrm{x} \\
54.6 \\
49.3 \\
50.2 \\
34.7 \\
56.9 \\
23.3\end{array}$ & $\begin{array}{l}x \\
46.3 \\
43.0 \\
25.0 \\
45.5 \\
23.6\end{array}$ & $\begin{array}{l}x \\
41.4 \\
27.1 \\
47.3 \\
37.4\end{array}$ & $\begin{array}{l}\mathrm{x} \\
24.4 \\
55.5 \\
20.2\end{array}$ & $\begin{array}{l}\mathrm{x} \\
43.9 \\
16.2\end{array}$ & $\begin{array}{l}x \\
23.2\end{array}$ \\
\hline $\begin{array}{l}10 \mathrm{~cm} \mathrm{DeO1} 04 / 22 / 02 \\
10 \mathrm{~cm} \mathrm{DeO1} \quad 04 / 24 / 02\end{array}$ & $\begin{array}{l}63.9 \\
63.5\end{array}$ & $\begin{array}{l}49.1 \\
44.8\end{array}$ & $\begin{array}{l}51.6 \\
57.3\end{array}$ & $\begin{array}{l}36.6 \\
37.7\end{array}$ & $\begin{array}{l}53.1 \\
55.1\end{array}$ & $\begin{array}{l}17.4 \\
15.8\end{array}$ & $\begin{array}{l}46.6 \\
44.2\end{array}$ \\
\hline
\end{tabular}

\section{Discussion}

The microphytobenthic communities sampled at different depths, in different floodplain lakes and in different seasons were quite similar. Although in field studies there is always a potential for covariation, it is hypothesized that during flooding when the three lakes become connected, water bodies are thoroughly mixed and species are redistributed, leading to a uniform species composition, resetting local succession. Only when the lakes become disconnected and mixing of water bodies does not take place for some time, local environmental variables will cause microphytobenthic community composition to diverge. This hypothesis is consistent with the concepts formulated by Ward \& Stanford (1995) and Pithart (1999) on riverine invertebrates and phytoplankton, respectively. Hence floodplain lakes may exemplify the environments where 'spatial factors' (Biggs 1995, Soininen 2007) overrule the effects of local physical and chemical parameters.
Roozen (2005) reported rapid divergence of nutrient regimes and plankton development after isolation of floodplain waters from the lower sections of the rivers Rhine and Meuse. A diverging water chemistry of disconnected floodplain lakes was also evident from the seasonal dynamics of nutrients and conductivity in the present study (Fig. 3). Mixing of the floodplain lakes is reflected by a uniform water chemistry and by a uniform species composition, demonstrated by the high values of similarity between communities. Similarity values of $>60 \%$ indicate replicate samples (Gauch 1982, Engelberg 1987) and this value was often reached or exceeded. The communities were dominated by Nitzschia and Navicula, unattached diatoms, which are susceptible to displacement (Cattaneo \& Kalff 1978, Peterson et al. 1990). Genera like Achnanthes and Gomphonema that grow attached to solid substrates were scarcely represented, except in sites that were disconnected for longer periods of time. The species Hantzschia amphioxys and Luticola mutica were 


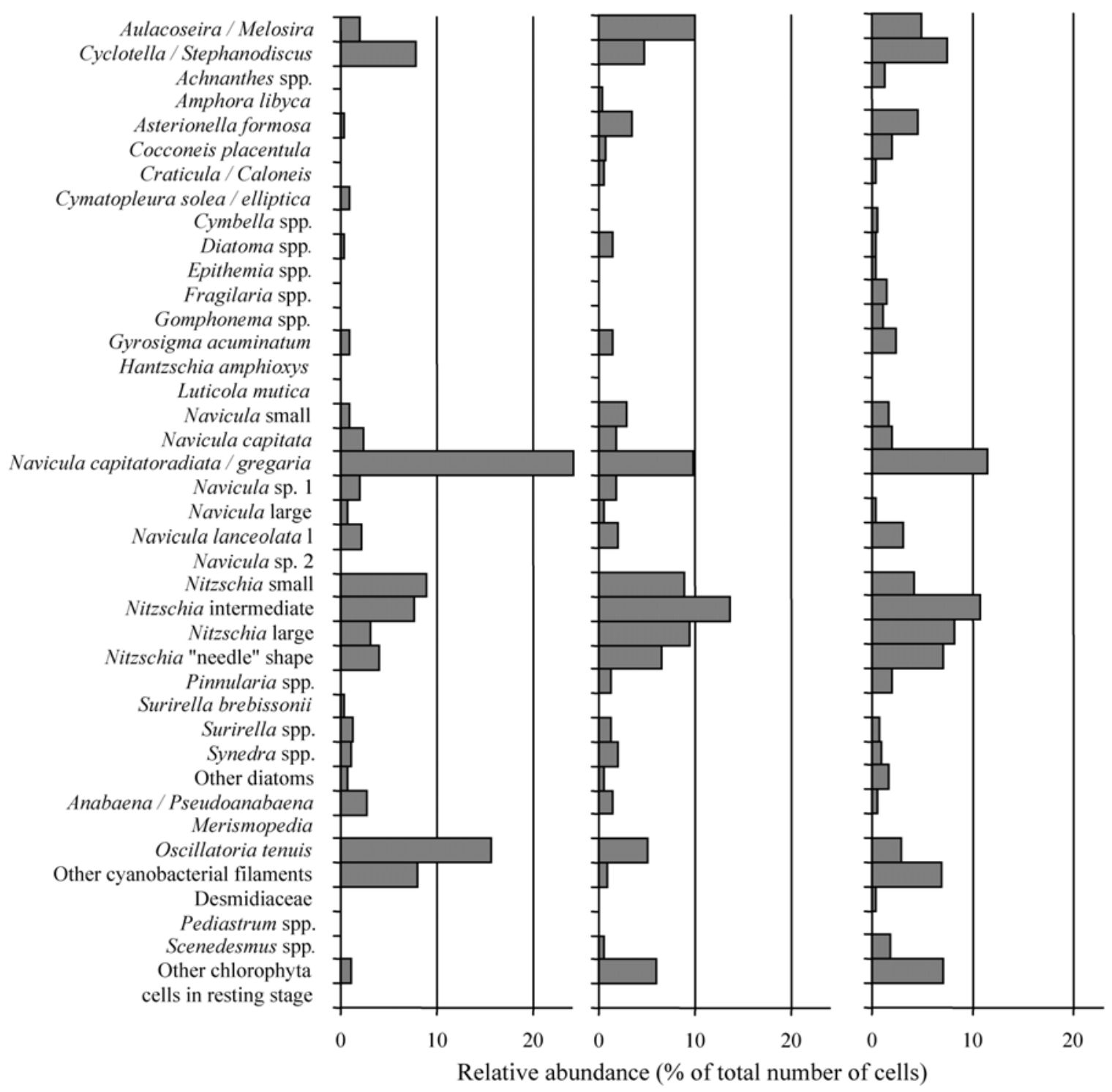

Fig. 4. Relative abundance of species (based on cell numbers) in the depth gradient sampled on $22.04 .2002 .10 \mathrm{~cm}, 75 \mathrm{~cm}$ and $200 \mathrm{~cm}$ : sampling depth.

found in post-flood samples. These species are known as cosmopolitan aerophylious species mainly occurring as soil diatoms in prolonged dry or temporarily wet environments (Krammer \& Lange-Bertalot 1988, Flechtner et al. 1998, Van de Vijver \& Beyens 1999). The presence of these species is indicative of terrestrial sediment being washed into the floodplain lakes (Medioli \& Brooks 2003). In agreement, De Fabricius et al. (2003) found high abundances H. amphioxys and $N$. mutica (a synonym of $L$. mutica) coinciding with high flow conditions.

Colijn \& Dijkema (1981), Underwood (1994) and Thornton et al. (2002) found that at high densities mi- crophytobenthic communities on dynamic intertidal mudflats were clearly dominated by one or a few species (relative abundance of $>65 \%$ in Thornton et al. 2002). In dense communities the most competitive species would be expected to drive less competitive species to extinction, and resources are partitioned among species whose realized niches do not overlap completely. However, this advanced state of succession requires prolonged interaction, and therefore, temporal heterogeneity (like disturbance) may prevent that this state is reached (Begon et al. 1996). This may explain why in our study many different species could coexist at low and high densities and the highest den- 
DeO1 spring 2000

DeO4 spring 2000

Och5 spring 2000

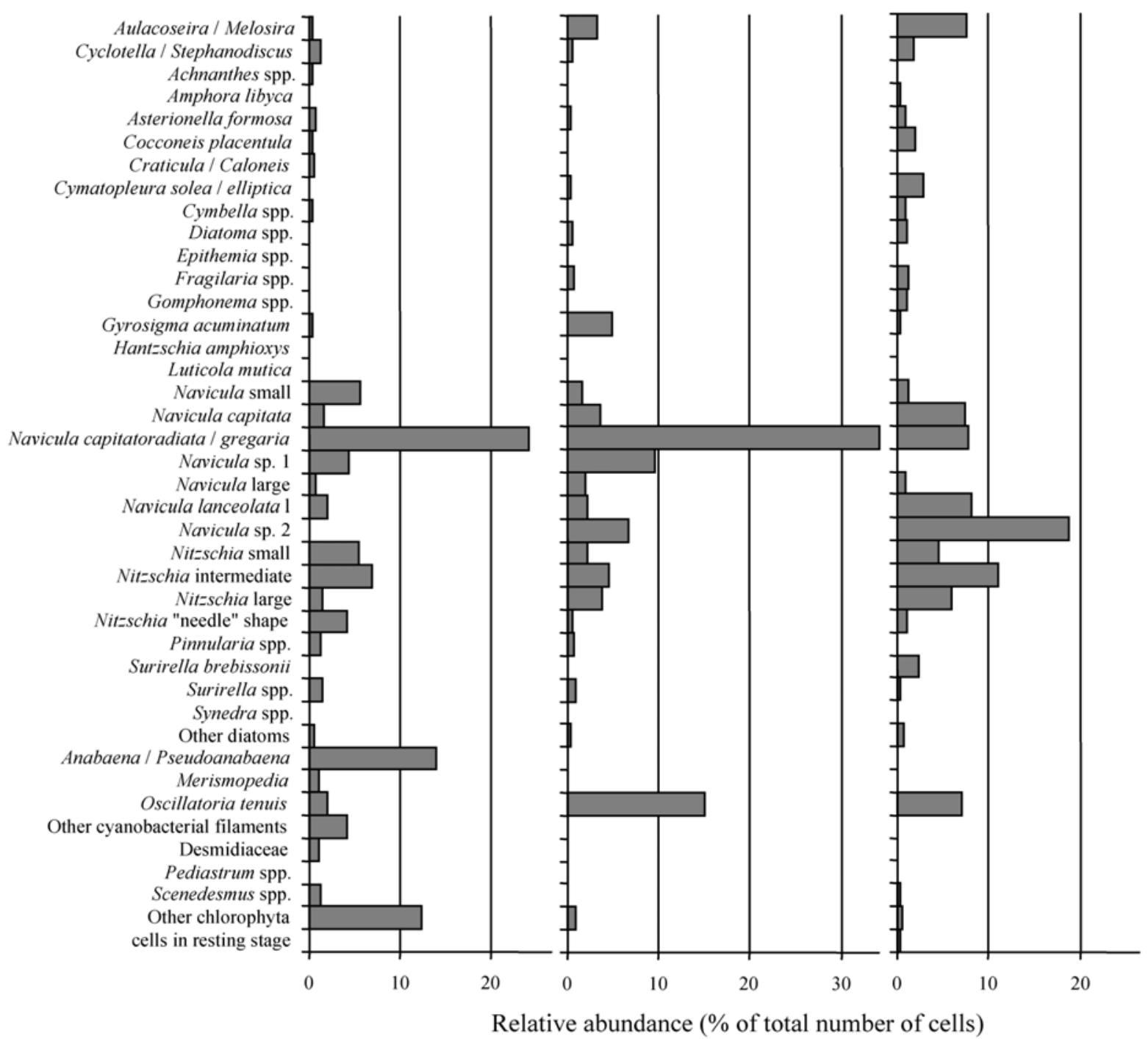

Fig. 5. Relative abundance of species (based on cell numbers) in the three lakes in spring 2000.

sity for a single taxon was $44 \%$, substantially lower than the $65 \%$ reported by Thornton et al. (2002).

When lakes become disconnected and disturbance and mixing do not take place for a prolonged period of time, animal communities (Ward \& Stanford 1995) and phytoplankton (Pithart 1999) develop differently according to local conditions in riverine micro-habitats. In the present study similar results were observed for microphytobenthos, indicated by the lower similarities between the three lakes in spring 2000 (max. 44 days of isolation) compared to spring 1999 (max. 34 days of isolation). Likewise, low similarities during prolonged isolation and high similarity caused by the next flooding in lake DeO1, indicate that seasonal succession is disrupted by flooding. A typical example of that was the winter 2000 sample that was dominated by resting cells of chlorophytes (relative abundance of $44.5 \%$ ). In the depth gradient, sampled 24-26 days after flooding, higher abundances of phytoplankton species at deeper sites were observed, due to a higher volume of water overlying the bottom.

In conclusion, floodplain lakes of large lowland rivers are thoroughly mixed at intervals and microphytobenthic species are extensively redistributed, leading to a uniform species composition. Yet disconnection of the floodplain lakes, triggers succession of species according to local environmental conditions. However, this divergence of community composition and diverging water chemistry is restricted to stable periods of disconnection from the river. 


\section{Acknowledgements}

We would like to thank Harm van de Geest, Kim de Mutsert and Jeroen Swinkels for taking samples by SCUBA diving.

\section{References}

Anagnostidis, K. \& Komarek, J., 1988: Modern approach to the classification-system of cyanophytes 3 - Oscillatoriales. - Archiv Hydrobiol. Suppl. 80: 327-472.

Begon, M., Harper, J. L. \& Townsend, C. R., 1996: Ecology: individuals, populations and communities (3rd ed.). - Blackwell scientific publications, Boston, $1068 \mathrm{pp}$.

Biggs, B. J. F., 1995: The contribution of flood disturbance, catchment geology and land use to the habitat template of periphyton in stream ecosystems. - Freshwat. Biol. 33: 419-438.

Bourrelly, P., 1966: Les algues d'eau douce: Initiation a la systematique I. Les algues vertes. - N. Boubee \& Cie, Paris, 572 pp.

- 1968: Les algues d'eau douce: Initiation a la systematique II. Les algues jaunes et brunes. - N. Boubee \& Cie, Paris, 438 pp.

- 1970: Les algues d'eau douce: Initiation a la systematique III. Eugleniens, Peridiniens, Algues rouges et Algues bleues. $-\mathrm{N}$. Boubee \& Cie, Paris, 512 pp.

Bray, J. R. \& Curtis, J. T., 1957: An ordination of the upland forest communities of Southern Wisconsin. - Ecol. Monogr. 27: 325-349.

Cattaneo, A. \& Kalff, J., 1978: Seasonal changes in the epiphyte community of natural and artificial macrophytes in Lake Memphremagog (Que. and Vt.). - Hydrobiologia 206: 1-10.

Clarke, K. R. \& Warwick, R. M., 1994: Change in marine communities: An approach to statistical analysis and interpretation. - Natural Environment Research Council, Plymouth Marine Laboratory, Plymouth, 129 pp.

Colijn, F. \& Dijkema, K. S., 1981: Species composition of benthic diatoms and distribution of chlorophyll a on an intertidal flat in the Dutch Wadden Sea. - Mar. Ecol.-Prog. Ser. 4: 9-21.

Cox, E. J., 1996: Identification of freshwater diatoms from live material. - Chapman \& Hall, London, 158 pp.

De Fabricius, A. L. M., Maidana, N., Gomez, N. \& Sabater, S., 2003: Distribution patterns of benthic diatoms in a Pampean river exposed to seasonal floods: the Cuarto River (Argentina) - Biodivers. Conserv. 12: 2443-2454.

Dodds, W. K., Biggs, B. J. F. \& Lowe, R. L., 1999: Photosynthesis-irradiance patterns in benthic microalgae: variations as a function of assemblage thickness and community structure. - J. Phycol. 35: 42-53.

Engelberg, K., 1987: Die diatomeen-Zonöse in einem Mittelgebirgsbach und die Abgenzung jahreszeitlicher Aspekte mit Hilfe der Dominanz-Identität. - Arch. Hydrobiol. 110: 217 236.

Flechtner, V. R., Johansen, J. R. \& Clark, W. H., 1998: Algal composition of microbiotic crusts from the Central Desert of Baja California, Mexico. - Great Basin Nat. 58: 295-311.

Gauch, H. G., 1982: Multivariate analysis in community ecology. - Cambridge University Press, Cambridge, 298 pp.

Hill, W. R., 1996: Effects of light. - In: Stevenson, R. J., Bothwell, M. L. \& Lowe, R. L. (eds.): Algal ecology: freshwater benthic ecosystems. - Academic Press, San Diego, pp. 121-148.

Kralj, K., Plenkovic-Moraj, A., Gligora, M., Primc-Habdija, B. \& Sipos, L., 2006: Structure of periphytic community on arti- ficial substrata: influence of depth, slide orientation and colonization time in karstic Lake Visovacko, Croatia. - Hydrobiologia 560: 49-258.

Krammer, K. \& Lange-Bertalot, H., 1986: Süßwasserflora van Mitteleuropa Band 2. Bacillariophyceae. Teil 1. Naviculaceae. - Gustav Fischer Verlag, Stuttgart-New York.

- - 1988: Süßwasserflora van Mitteleuropa Band 2. Bacillariophyceae. Teil 2. Bacillariaceae, Epithemiaceae, Surirellaceae. - Gustav Fischer Verlag, Stuttgart-New York.

- - 1991a: Süßwasserflora van Mitteleuropa Band 2. Bacillariophyceae. Teil 3. Centrales, Fragilariaceae, Eunotiaceae. - Gustav Fischer Verlag, Stuttgart-New York.

- - 1991b: Süßwasserflora van Mitteleuropa Band 2. Bacillariophyceae. Teil 4. Achnanthaceae. Kritische Ergänzungen zu Navicula (Lineolatae) und Gomphonema. - Gustav Fischer Verlag, Stuttgart-New York.

Lorenzen, C. J., 1967: Determination of Chlorophyll and pheopigments: spectrophotometric equations. - Limnol. Oceanogr. 12: 343-346.

Medioli, B. E. \& Brooks, G. R., 2003: Diatom and thecamoebian signatures of Red River (Manitoba and North Dakota) floods: Data collected from the 1997 and 1999 spring freshets. - J. Paleolimnol. 29: 353-386.

Peterson, C. G., Hoagland, K. D. \& Stevenson, R. J., 1990: Timing of wave disturbance and the resistance and recovery of a freshwater epilithic microalgal community. - J. N. Amer. Benthol. Soc. 9: 54-67.

Pielou, E. C., 1966: The measurement of diversity in different types of biological collections. - J. Theor. Biol. 13: 131-144.

Pithart, D., 1999: Phytoplankton and water chemistry of several alluvial pools and oxbows after the flood event - a process of diversification. - Arch. Hydrobiol. Suppl. Algol. Stud. 130: 93-113.

Rijkswaterstaat: 2003. - Rijksinstituut voor Kust en Zee, http:// www.base.nl

Roozen, F. C. J. M., 2005: Transparency of floodplain lakes. $\mathrm{PhD}$ Thesis, Wageningen University, Wageningen, The Netherlands

Shannon, C. E. \& Weaver, W., 1963: The mathematical theory of communication. - University Illinois Press, Urbana, 117 pp.

Soininen, J., 2007: Environmental and spatial control of freshwater diatoms - a review. - Diatom Res. 22: 473-490.

Thornton, D. C. O., Dong, L. F., Underwood, G. J. C. \& Nedwell, D. B., 2002: Factors affecting microphytobenthic biomass, species composition and production in the Colne Estuary (UK). - Aquat. Microb. Ecol. 27: 285-300.

Tuji, A., 2000: The effect of irradiance on the growth of different forms of freshwater diatoms: implications for succession in attached diatom communities. - J. Phycol. 36: 659-661.

Underwood, G. J. C., 1994: Seasonal and spatial variation in epipelic diatom assemblages in the severn etuary. - Diatom Res. 9: $451-472$.

Van de Vijver, B. \& Beyens, L., 1999: First contribution to the diatom flora of the Amsterdam Island (TAAF). Ann. Limnol. Internat. J. Limnol. 35: 85-94.

Ward, J. V. \& Stanford, J. A., 1995. Ecological connectivity in alluvial river ecosystems and its disruption by flow regulation. - Regul. Riv.: Res. Manage. 11: 105-119.

Wellnitz, T. \& Rinne, B., 1999: Photosynthetic response of stream periphyton to fluctuating light regimes. - J Phycol. 35: 667-672. 